\title{
Model Alur Kerja Penanganan Bukti Digital Untuk Data Multimedia
}

\author{
Dirman*1, Yudi Prayudi $^{2}$, Erika Ramadhani ${ }^{3}$ \\ ${ }^{1,2}$ Universitas Islam Indonesia; Yogyakarta, (0274) 895287 \\ ${ }^{3}$ Forensika Digital, Magister Informatika, FTI, Yogyakarta \\ e-mail:*11dirman@students.uii.ac.id, ${ }^{2}$ prayudi@uii.ac.id, ${ }^{3}$ erika@uii.ac.id
}

\begin{abstract}
Abstrak
Kejahatan multimedia melalui platform dan transmisi digital merupakan kondisi yang sangat serius dan merugikan. Dewasa ini, kasus digital multimedia tidak sedikit menjadi perhatian, terutama dalam penanganan bukti multimedia yang dapat digunakan sebagai instrumen penentu kebenaran ilmiah di pengadilan. Selain itu juga, barang bukti digital multimedia sangat mudah dilakukan modifikasi dengan menggunakan aplikasi yang bisa digunakan secara bebas, sehingga keaslian data digital bisa saja rusak atau hilang. Tantangan yang dihadapi investigator dalam penanganan bukti digital multimedia adalah tuntutan variabel keabsahan proses penyidikan, penanganan, dokumentasi hingga pelaporan. Layaknya prosedur penanganan pada umumnya, investigasi kasus digital multimedia membutuhkan alur kerja sehingga tahapan investigasi bisa terkontrol dengan baik. Penelitian ini mengkaji framework, SOP dan alur kerja penanganan bukti digital. Hasil pemetaan dan kajian digunakan sebagai pembuatan model alur kerja penanganan bukti digital untuk data multimedia dengan menggunakan metode design thinking dengan pendekatan Business Process Model and Notation (BPMN) dalam mendapatkan hubungan antara aktor, bukti digital dan alur kerja.
\end{abstract}

Kata kunci-Alur Kerja, Forensik Multimedia, Design Thinking, BPMN, Bukti Multimedia

\begin{abstract}
Multimedia crime through digital platforms and transmission is a severe and detrimental condition. Nowadays, digital multimedia cases have received much attention, especially in handling multimedia evidence that can be used as an instrument to determine scientific truth in court. In addition, multimedia digital evidence is straightforward to modify using applications that can be used freely so that the authenticity of digital data can be damaged or lost. The challenge faced by investigators in handling multimedia digital evidence is the variable demands for the investigation's validity, handling, documentation, and reporting processes. Like handling procedures in general, digital multimedia case investigations require a workflow so that the investigation stages can be well controlled. This study examines the framework, standard operating procedures, and workflows for handling digital evidence. The results of the mapping and study are used as a workflow model for handling digital evidence for multimedia data by using the design thinking method with the Business Process Model and Notation $(B P M N)$ approach in getting the relationship between actors, digital evidence, and workflows.
\end{abstract}

Keywords-Workflow, Multimedia Forensics, Design Thinking, BPMN, Multimedia Evidence 


\section{PENDAHULUAN}

Perkembangan teknologi yang semakin masif yang diikuti dengan beragamnya kejahatan dalam dunia digital mengharuskan pengguna lebih berhati-hati berinteraksi menggunakan platform digital [1]. Di dunia multimedia forensik masih memiliki tantangan serius terkait data multimedia. Pada tahun 2016 di Indonesia dikagetkan dengan kasus kopi sianida [2]. Kasus tersebut saat itu memiliki barang bukti berupa data digital multimedia, yakni data video yang berasal dari CCTV di tempat kejadian. Kondisi saat itu masih minim sosialisasi secara penuh terhadap ahli hukum dan persidangan tentang bagaimana memperlakukan barang bukti digital multimedia. Akibatnya, keaslian dari barang bukti dipertanyakan. Sehingga semakin memperpanjang kondisi dalam memutuskan siapa pelaku kejahatan.

Kasus yang terjadi yang berkaitan dengan data multimedia, data Patroli Siber sepanjang Januari 2015 hingga Februari 2021, jumlah penipuan berkisar 8.541 kasus online, manipulasi data 331, penyebaran konten provokatif 7.460 yang berpotensi memuat data multimedia. Angka-angka ini menunjukan dunia teknologi, digital dan elektronik masih sangat rentan terhadap masalah kejahatan yang dapat menimbulkan kerugian pada masyarakat. Tren siber crime juga masih menyentuh angka 200-an kasus pada tahun 2020 [3]. Permasalahan lain yang dihadapi pada penanganan bukti digital multimedia adalah bukti sangat mudah dilakukan modifikasi, sehingga keaslian data bisa saja hilang seiring dengan proses perlakuan yang salah terhadap penanganan data digital tersebut. Secara umum, hal inilah yang menyebabkan proses penanganan bukti digital multimedia lebih beragam tantangannya. Sehingga perlunya alur kerja dalam proses digital forensik dan tentu hubungan ahli forensik dan bukti digital merupakan hal dasar dan penting [4].

Menyadari maraknya kejahatan digital yang terjadi, telah banyak merugikan lembaga atau negara [5] sehingga dipandang penting sebuah alur kerja dalam mengungkap kejahatan [6]. Untuk menunjang keberhasilan proses digital forensik dibutuhkan alur kerja untuk memperoleh keselarasan hasil [7]. Karena data multimedia masih memiliki corak yang khas dari bukti digital lain [8]. Penanganan barang bukti digital yang benar adalah sangat krusial dan bukti digital yang bisa digunakan pada ranah persidangan harus memiliki dasar yang kuat [9]. Penelitian ini mendesain model alur kerja penanganan bukti digital untuk data multimedia. Memetakan hubungan aktor dan bukti digital multimedia. Metode yang digunakan untuk membangun alur kerja, dibuat berdasarkan pada metode design thinking yang digunakan untuk mendapatkan data awal penelitian, kebutuhan sistem, perasaan yang dialami aktor atau ahli forensik dan menggunakan pendekatan Business Process Model and Notation (BPMN) untuk membuat alur kerja, mendapatkan hubungan aktor dan bukti digital multimedia.

\section{METODE PENELITIAN}

Langkah penelitian ini, pertama memberikan gambar alur yang ditempuh dari awal hingga akhir penelitian. Mulai dari identifikasi masalah sehingga diperoleh judul penelitian terkait pembuatan model alur kerja penanganan bukti digital untuk data multimedia. Kemudian literatur review, mencari dokumen berupa jurnal terdahulu sehingga hasil filter di peroleh enam dokumen penanganan bukti digital. Selanjutnya untuk mendapatkan empathize, define, ideate, prototype dan test dengan menggunakan metode design thinking. Tahap evaluasi sebagai proses memberikan ulasan dari alur kerja yang dihasilkan. Terakhir hasil laporan kesimpulan yang diperoleh dari penelitian, jurnal dan laporan tugas akhir. Lima langkah penelitian ditunjukan pada Gambar 1. 


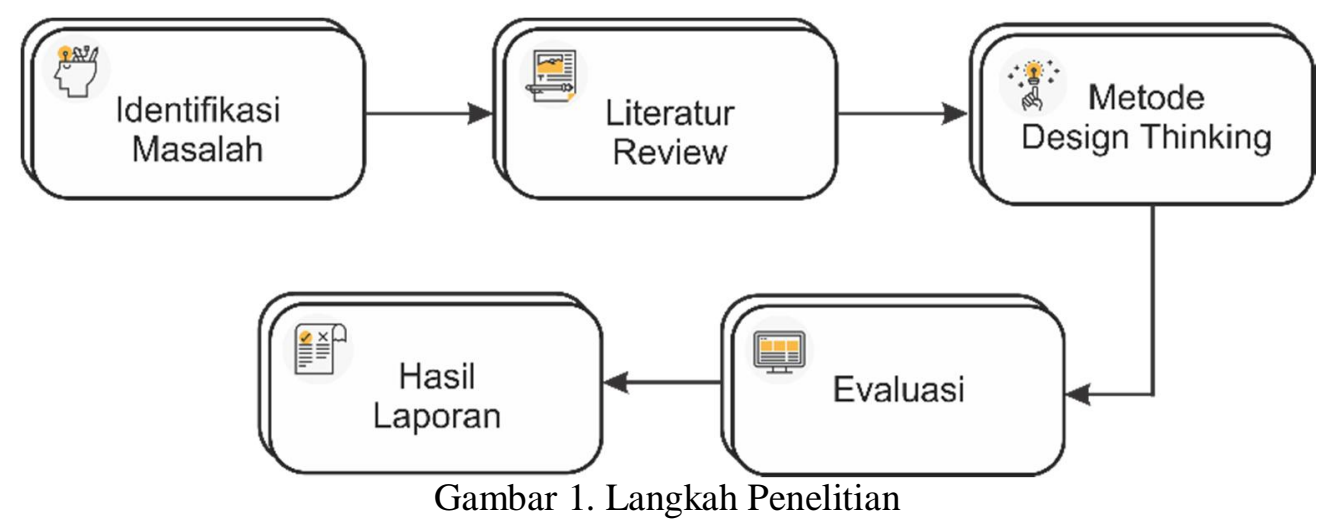

Penggunaan design thinking untuk menjadi instrumen menyelesaikan problem penelitian. design thinking memiliki struktur yang sangat mendukung untuk mendapatkan kebutuhan dari ketiadaan data awal. Tindakan yang dilakukan adalah lima tahapan sub-design thinking, mulai dari empathize, define, ideate, prototype dan test. Untuk mendapatkan model alur kerja menggunakan metode pendekatan Business Process Model and Notation (BPMN) di Gambar 2.

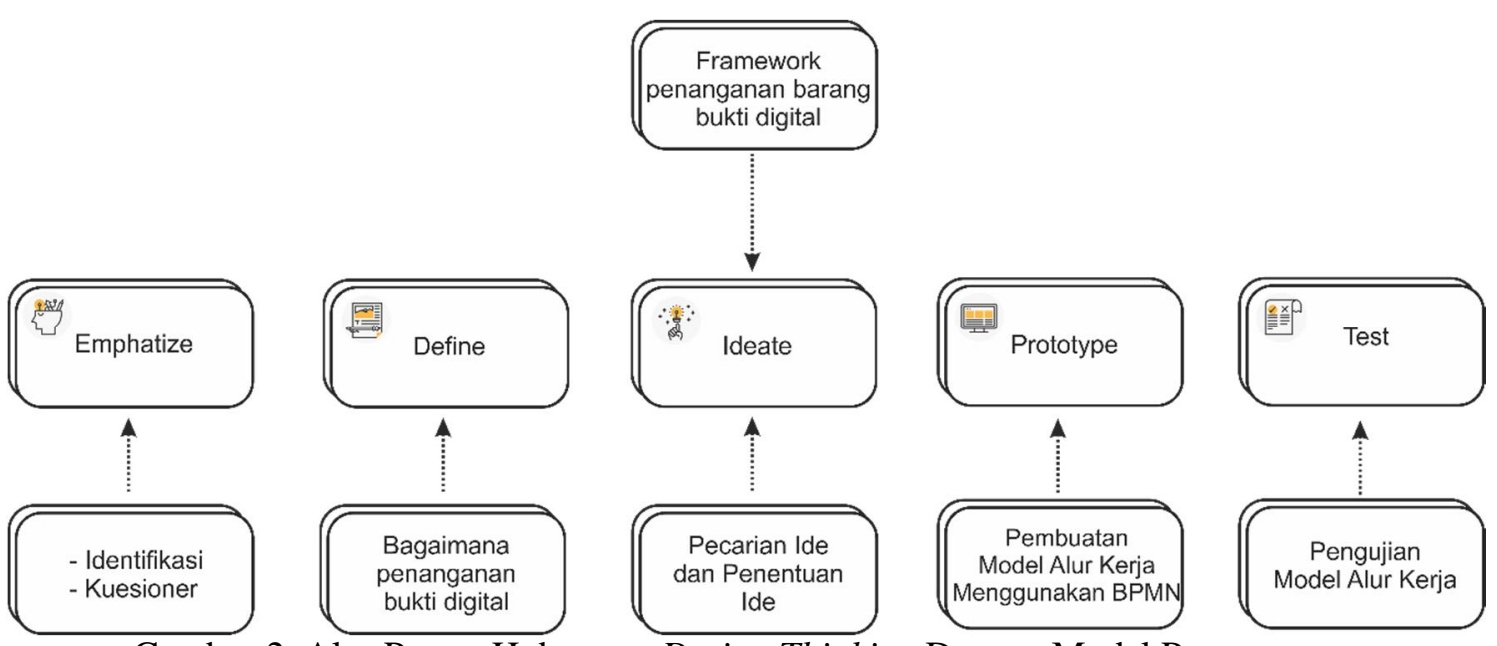

Gambar 2. Alur Proses Hubungan Design Thinking Dengan Model Perancangan

\subsection{Empathize}

Empathize untuk mendapatkan pemahaman empatik dari user. Apa sebenarnya yang diharapkan oleh pengguna dalam masalah yang sedang dihadapi. Selain itu, terdapat dua tahap proses identifikasi data framework, alur kerja dan kuesioner untuk mengumpulkan data dari praktisi multimedia forensik.

\subsection{Define}

Define menerjemahkan analisis dan disintesis dari empathize. Hasil dari fase define membantu memperoleh informasi konten perencanaan pemecahan masalah yang dihadapi user dalam menghadapi berbagai kasus yang menyangkut urusan penangan dalam dunia forensik digital karena telah dilakukan penetapan final masalah. 


\subsection{Ideate}

Tahap ideate bersumber dari proses empathize dan define untuk memberikan brainstorming gagasan dan menentukan solusi ide-ide yang dianggap penting untuk disampaikan. Selanjutnya implementasi ide pada proses prototype.

\subsection{Prototype}

Pada tahap prototype ini akan dihasilkan versi produk model alur kerja yang sistematis dengan menggunakan pendekatan Business Process Model and Notation (BPMN).

\subsection{Test}

Proses pengujian dari produk model alur kerja penanganan bukti digital untuk data multimedia dilakukan dengan memvalidasi elemen dari alur kerja.

\section{HASIL DAN PEMBAHASAN}

\subsection{Empathize}

Empathize sebagai proses evaluasi dan analisis yang berkaitan dengan data, aktor serta evidence yang bersumber dari hasil identifikasi. Penelitian ini mengeksplorasi beberapa data evaluasi dan analisis yang menghasilkan beberapa tabel. Tabel 1, terdapat 8 dokumen yang berisi hasil analisis penanganan bukti digital yang di seleksi sesuai variabel tahapan alur preparation, collection, examination, analysis dan reporting. Tabel 2, terdapat 5 dokumen hasil analisis multimedia forensik dan Tabel 3, terdapat 4 dokumen identifikasi sumber daya manusia yang dijadikan kebutuhan untuk mendapatkan aktor, bukti digital dan pemetaan hubungan yang digunakan dalam pembuatan alur kerja penanganan bukti digital untuk data multimedia. Berikut penjabaran lebih lanjut:

Tabel 1. Identifikasi Model Alur Kerja Penanganan Bukti Digital

\begin{tabular}{|c|c|c|c|}
\hline No & Peneliti/Lembaga & Nama Model/Judul & Keterangan Alur \\
\hline 1 & $\begin{array}{l}\text { (Cohen., 2009) } \\
{[10]}\end{array}$ & $\begin{array}{l}\text { Abstract Digital } \\
\text { Forensics Model } \\
\text { (ADFM) }\end{array}$ & $\begin{array}{l}\text { Identification, Preparation, Approach } \\
\text { Strategy, Preservation, Collection, } \\
\text { Examination, Analysis, Presentation, } \\
\text { Returning Evidence }\end{array}$ \\
\hline 2 & $\begin{array}{l}\text { (Rogers et al., } \\
\text { 2006) [11] }\end{array}$ & $\begin{array}{l}\text { Computer Forensics } \\
\text { Field Triage Process } \\
\text { Model (CFFTPM) }\end{array}$ & $\begin{array}{l}\text { Planning, Triage, User Usage Profile, } \\
\text { Chronology, Timeline, Internet, Case } \\
\text { Specific }\end{array}$ \\
\hline 3 & $\begin{array}{l}\text { Korolev \& } \\
\text { Kuchanov., 1982) } \\
{[12]}\end{array}$ & $\begin{array}{l}\text { Digital Forensics } \\
\text { Research Workshop } \\
\text { (DFRWS) } \\
\end{array}$ & $\begin{array}{l}\text { Identification, Preservation, Collection, } \\
\text { Examination, Analysis, Presentation }\end{array}$ \\
\hline 4 & $\begin{array}{l}\text { Perumal \& } \\
\text { Norwiwi, 2009) } \\
{[13]}\end{array}$ & $\begin{array}{l}\text { Digital Forensic } \\
\text { Model On Malaysian } \\
\text { Investigation Process } \\
\text { (DFMMIP) }\end{array}$ & $\begin{array}{l}\text { Planning, Identification, Reconnaissance, } \\
\text { Transport \& Storage, Analysis, Proof \& } \\
\text { Defense, Archive Storage }\end{array}$ \\
\hline 5 & $\begin{array}{l}\text { (Kent \& } \\
\text { Souppaya., 2006) }\end{array}$ & $\begin{array}{l}\text { National Institute Of } \\
\text { Standards and }\end{array}$ & Collection, Examination, Analysis, \\
\hline
\end{tabular}




\begin{tabular}{llll}
\hline & {$[14]$} & Technology & Reporting \\
\hline 7 & POLRI & SOP Laboratorium & Memiliki 15 SOP \\
& & Forensik Digital & \\
& & POLRI & \\
\hline 8 & POLRI & Aturan Yuridis No. & Legalitas, Transparan, Proporsional, \\
& & 10/2010 Prosedur & Akuntabel, Efektif dan efisien \\
& & Penanganan Barang & \\
& & Bukti Digital & \\
\hline
\end{tabular}

Tabel 2. Identifikasi Penanganan Bukti Digital Multimedia

\begin{tabular}{|c|c|c|c|}
\hline No & Peneliti/Lembaga & Nama Model/Judul & Keterangan \\
\hline 1 & $\begin{array}{l}\text { (Lizarti et el., } \\
\text { 2017) [15] }\end{array}$ & $\begin{array}{l}\text { Penerapan composite logic dalam } \\
\text { mengkolaborasikan framework terkait } \\
\text { multimedia forensik }\end{array}$ & $\begin{array}{l}\text { Metode composite } \\
\text { logic }\end{array}$ \\
\hline 2 & $\begin{array}{l}\text { (Ledesma., 2015) } \\
\text { [16] }\end{array}$ & $\begin{array}{l}\text { A proposed framework for forensic } \\
\text { image enhancement }\end{array}$ & $\begin{array}{l}\text { Image enhancement } \\
\text { pada citra digital }\end{array}$ \\
\hline 3 & $\begin{array}{l}\text { (Al-Azhar., 2012) } \\
\text { [17] }\end{array}$ & Audio Forensics Analyst & Forensics Analyst \\
\hline 4 & $\begin{array}{l}\text { (SWGDE., 2010) } \\
{[18]}\end{array}$ & $\begin{array}{l}\text { SWGD minimum requirement for } \\
\text { quality assurance in the processing of } \\
\text { digital and multimedia evidence }\end{array}$ & $\begin{array}{l}\text { Minimum requirement } \\
\text { pada multimedia }\end{array}$ \\
\hline 5 & $\begin{array}{l}\text { (Al Shaikh \& } \\
\text { Sedky., 2015) [19] }\end{array}$ & $\begin{array}{l}\text { Post incident analysis framework for } \\
\text { automated video forensic investigation }\end{array}$ & $\begin{array}{l}\text { Otomatisasi investigasi } \\
\text { forensik video }\end{array}$ \\
\hline
\end{tabular}

Hasil identifikasi penanganan bukti digital multimedia berdasarkan tahap dalam penanganan bukti digital. Dalam pemetaan menggunakan variabel.

Dalam pembuatan alur kerja penanganan bukti digital untuk data multimedia dibutuhkan keterlibatan ahli forensik yang menjadi aktor penting dalam penanganan tindakan kejahatan di dunia digital. Berikut empat dokumen investigasi dan identifikasi hasil dari sumber daya manusia, aktor atau personil:

Tabel 3. Identifikasi Sumber Daya Manusia, Aktor atau Personil

\begin{tabular}{lll}
\hline No & \multicolumn{1}{c}{ Peneliti/Lembaga } & \multicolumn{1}{c}{ Keterangan Aktor/Personil } \\
\hline 1 & (NIST, 2006) & Investigator, Professionals dan Insiden handlers \\
\hline 2 & (Cosic, 2012) [20] & First responder, Forensic investigator, Court expert witness, \\
& & Law enforcement personal/police officer or crime inspector, \\
& & Victim, Suspect dan Passerby. \\
\hline 3 & (SNI ISO/IEC & $\begin{array}{l}\text { Digital Evidence First Responder (DEFR), Digital Evidence } \\
\text { Special (DES), dan Othe Authorities. }\end{array}$ \\
\hline 4 & (Subektiningsih, & First responder, Investigators, Petugas Kepolisian, dan \\
& 2017)[21] & Profesional IT \\
\hline
\end{tabular}

\subsection{Wawancara}

Hasil dari wawancara yang diperoleh adalah enam data sebagai feedback permasalah user dalam problem kebutuhan alur kerja forensik multimedia, pentingnya alur kerja, keterlibatan aktor, jenis barang bukti multimedia yang selama ini ditangani. Adapun data yang diperoleh yaitu dari Yana (profesional IT), Pratomo Djati Nugroho (dosen digital forensik dan profesional IT), Ayubi Wirara (staf subdirektorat forensik digital dan analisis kripto), Nur Amin Kadir 
(digital forensic examiner), Grawas Sugiharto (pemeriksa digital forensik PUSLABFOR POLRI), Buyung Gde (petugas kepolisian) dan no name (penyidik, penyidik digital, penyidik forensik, dosen digital forensik).

\subsection{Define}

Define merupakan ulasan problem dari user atau aktor yang bersumber dari empathize. Hasilnya adalah terdapat beberapa masalah yang sedang dihadapi, pertama masih ada problem pemeriksaan barang bukti, perkembangan teknologi saat ini masih menjadi permasalahan penting dalam menghadapi fenomena kebaruan modus kejahatan dan proses penanganan. Sedangkan tantangan user, keberadaan evidence hasil editing, banyaknya sumber bukti digital, alur kerja yang terpublikasi alur kerja dimanfaatkan pihak lawan untuk menyerang, barang bukti rusak atau terhapus dan penentuan asal bukti original. Sedangkan aktor yang terlibat pertama forensics analyst, team Digital Forensics and Incident Response (DFIR), Badan Siber dan Sandi Negara (BSSN), penyelidik, ahli forensik, pengelola digital forensik, petugas penerima barang bukti, petugas ruangan bukti digital, pemeriksa barang bukti. Dari beberapa data dari aktor yang digunakan dalam penelitian ini difokuskan pada kebutuhan membuat model alur kerja.

\subsection{Ideate}

Proses pencarian ide, penentuan ide menggunakan metode Now Wow How Matrix. Metode ini dapat menyerap tiga perspektif yang berbeda dalam pemilihan ide untuk model alur kerja penanganan bukti digital untuk data multimedia. Dalam definisi, bahwa Now sebagai instrumen ide yang dapat diaplikasikan dengan kurun waktu yang cepat. Wow sebagai instrumen ide bisa menjadi pilihan untuk melakukan inovatif dan diimplementasikan [22]. Dan terakhir How adalah instrumen ide yang menjadi opsi untuk inovatif dan diterapkan. Hasil Now Wow How Matrix dibuat dengan tampilan brainstorming matrix sederhana. Adapun hasil dapat dilihat pada Gambar 1:

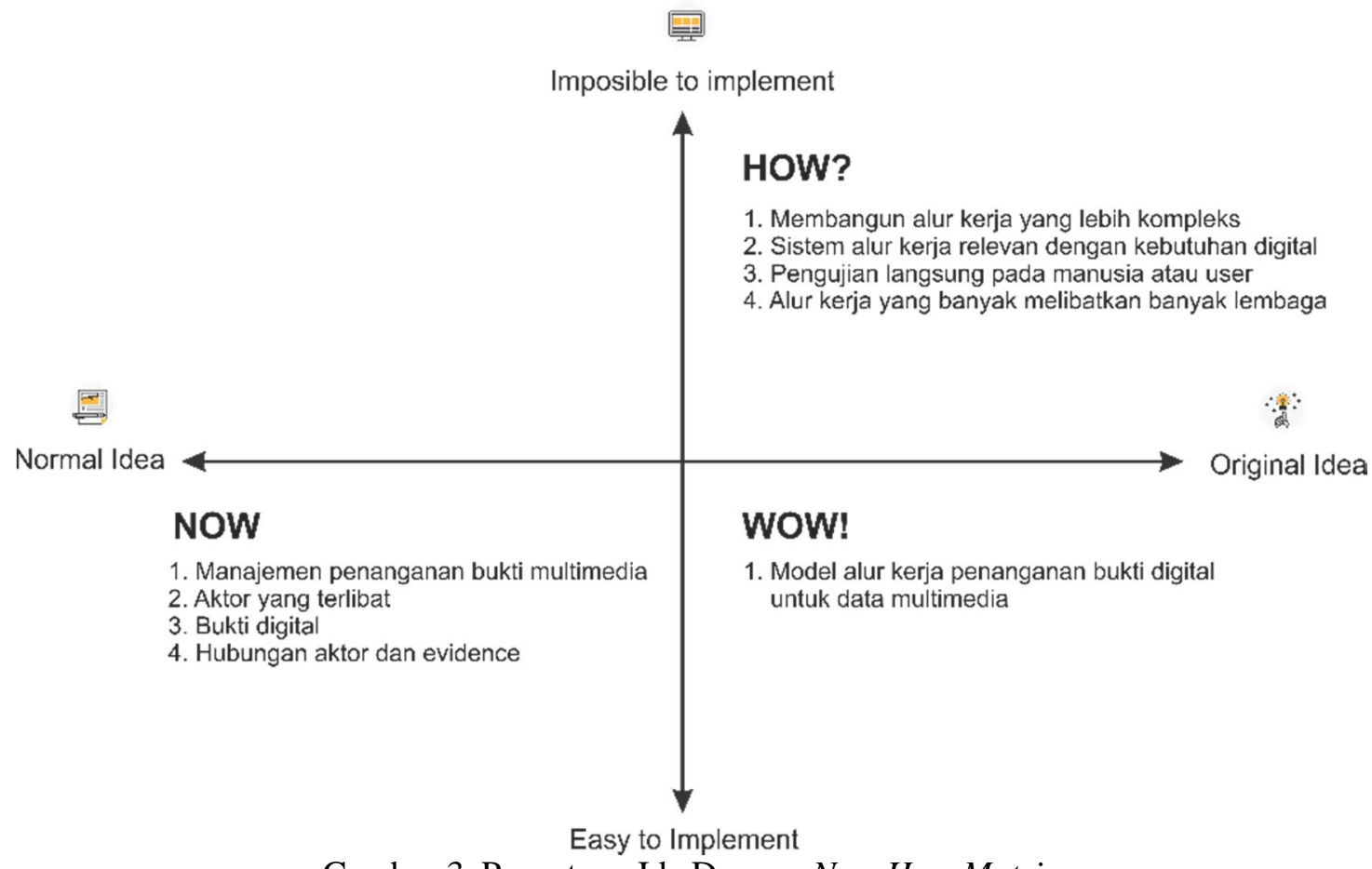

Gambar 3. Penentuan Ide Dengan Now How Matrix 


\subsection{Prototype}

Setelah melalui tahapan empathize, define dan ideate. Selanjutnya prototype dibuat dengan metode Business Process Model and Notation (BPMN) mendapatkan model proses dengan menggunakan bantuan tools diagram Bizagi yang dapat membangun model. Konten BPMN alur kerja forensik data multimedia adalah hasil dari proses metode empathize, define dan ideate yang telah dikonversi menjadi bagian-bagian proses model alur kerja. Penjelasan dari model alur kerja penanganan bukti digital untuk data multimedia ini secara umum menentukan keterlibatan aktor, evidence dan hubungan model proses penanganan bukti digital untuk data multimedia dengan tetap memperhatikan penggunaan elemen Business Process Model and Notation (BPMN).

Business Process Model and Notation (BPMN) mampu diterapkan dalam pembuatan alur kerja forensik multimedia, memberikan informasi hubungan evidence dan aktor first responder, Investigator, Profesional IT, Petugas Kepolisian yang akan bertugas memberikan penanganan terhadap insiden yang terjadi. Berikut adalah penjelasan hasil dari proses Business Process Model and Notation (BPMN) yang dapat ditinjau di Tabel 4 dan desain alur kerja menggunakan BPMN dapat dilihat pada Gambar 4:

Tabel 4. Penjelasan Hasil Alur Kerja

\begin{tabular}{|c|c|c|}
\hline No & Alur Kerja & Bagian \\
\hline 1 & $\begin{array}{l}\text { Fase awal dalam kasus digital forensik adalah insiden respon } \\
\text { terkait kemungkinan yang akan menjadi penyelidikan, } \\
\text { memastikan tempat yang menjadi area penyelidikan; }\end{array}$ & \multirow{15}{*}{$\begin{array}{c}\text { First responder/ } \\
\text { Investigator / } \\
\text { Profesional IT / } \\
\text { Petugas Kepolisian }\end{array}$} \\
\hline 2 & $\begin{array}{l}\text { Sebagai investigator forensik menyampaikan proses izin lanjut } \\
\text { penyelidikan; }\end{array}$ & \\
\hline 3 & $\begin{array}{l}\text { Mempersiapkan dan memahami kembali prosedur standar dalam } \\
\text { penanganan kasus digital forensik; }\end{array}$ & \\
\hline 4 & Melakukan proses pendokumentasian, observasi di sekitar TKP; & \\
\hline 5 & $\begin{array}{l}\text { Mengumpulkan barang-barang bukti yang telah ditemukan di } \\
\text { TKP; }\end{array}$ & \\
\hline 6 & $\begin{array}{l}\text { Barang bukti yang terkumpul dan terindikasi kuat, berhubungan } \\
\text { dilakukan penyitaan; }\end{array}$ & \\
\hline 7 & $\begin{array}{l}\text { Barang bukti yang telah disita, selanjutnya diamankan untuk } \\
\text { menghindari kerusakan pada bukti penyitaan; }\end{array}$ & \\
\hline 8 & $\begin{array}{l}\text { Akuisisi bukti ini dilakukan pada file bukti dan system yang } \\
\text { bersumber dari TKP. }\end{array}$ & \\
\hline 9 & $\begin{array}{l}\text { File bukti dan system untuk memisalkan jenis bukti digital } \\
\text { multimedia; }\end{array}$ & \\
\hline 10 & $\begin{array}{l}\text { Akuisisi video, langkah untuk mengolah bukti digital video } \\
\text { penyitaan. }\end{array}$ & \\
\hline 11 & Video dieksraksi sebagai upaya mengembalikan kebenaran video; & \\
\hline 12 & Memperoleh salinan dari penyimpanan (HDD Cloning); & \\
\hline 13 & $\begin{array}{l}\text { Akuisisi audio, langkah untuk mengelola bukti digital audio } \\
\text { penyitaan; }\end{array}$ & \\
\hline 14 & $\begin{array}{l}\text { Akuisisi gambar, langkah untuk mengelola bukti digital gambar } \\
\text { penyitaan; }\end{array}$ & \\
\hline 15 & $\begin{array}{l}\text { Record log, mendapatkan rekaman catatan dari hasil akuisisi } \\
\text { gambar; }\end{array}$ & \\
\hline 16 & $\begin{array}{l}\text { Memisahkan bukti elektronik yang telah memalui proses } \\
\text { pengambilan bukti digital multimedia; }\end{array}$ & \\
\hline
\end{tabular}


17 Bukti elektronik di simpan ke penyimpanan fisik untuk menjaga keaslian barang bukti;

18 Bukti digital multimedia disimpan ke lemari bukti digital untuk menjaga keamanan dan keaslian bukti digital;

19 Mengambil bukti multimedia dari penyimpanan;

20 Analisis bukti multimedia yang telah melalui proses akuisisi;

21 Menganalisis bukti video secara otomatis;

22 Menganalisis bukti video secara manual;

23 Mengkonversi bukti video yang telah dianalisis;

24 Capturing hasil analisis dan konversi bukti video;

25 Menganalisis secara otomatis dan manual pada bukti audio;

26 Audio enhancement, memastikan kebenaran bukti audio. Peningkatan atau perbaikan;

27 Penguraian kode pada bukti digital audio (decoding)

28 Memastikan kebenaran terhadap suara pada audio (Voice recognition)

29 Menganalisis otomatis dan manual pada bukti gambar;

30 Melihat analisis dari gambar (visual analysis);

31 Mempertimbangkan analisis pada bukti gambar (consideration);

32 Memastikan artefak gambar yang benar (correct image artifact);

33 Mengubah urutan yang ke ukuran sebenarnya (resize);

34 Memberikan resolusi yang baik pada gambar tanpa mengubah data gambar (super-resolution);

35 Melakukan de-noise pada bukti gambar;

36 Melakukan de-blur pada bukti gambar;

37 Melakukan distortion correction pada bukti gambar;

38 Melakukan proses kontras/warna;

39 Sharpen, mempertajam pada bukti digital;

40 Bukti digital multimedia telah selesai proses analisis;

41 Penilaian bukti digital multimedia;

42 Pembuatan laporan penanganan bukti digital multimedia;

43 Kronologi semua pendokumentasian bukti digital multimedia;

44 Presentasi hasil pendokumentasian bukti digital multimedia di pengadilan (court presentation);

First responder/

Investigator /

Profesional IT /

Petugas Kepolisian

45 Memberikan kesaksian terhadap barang bukti digital di pengadilan; 


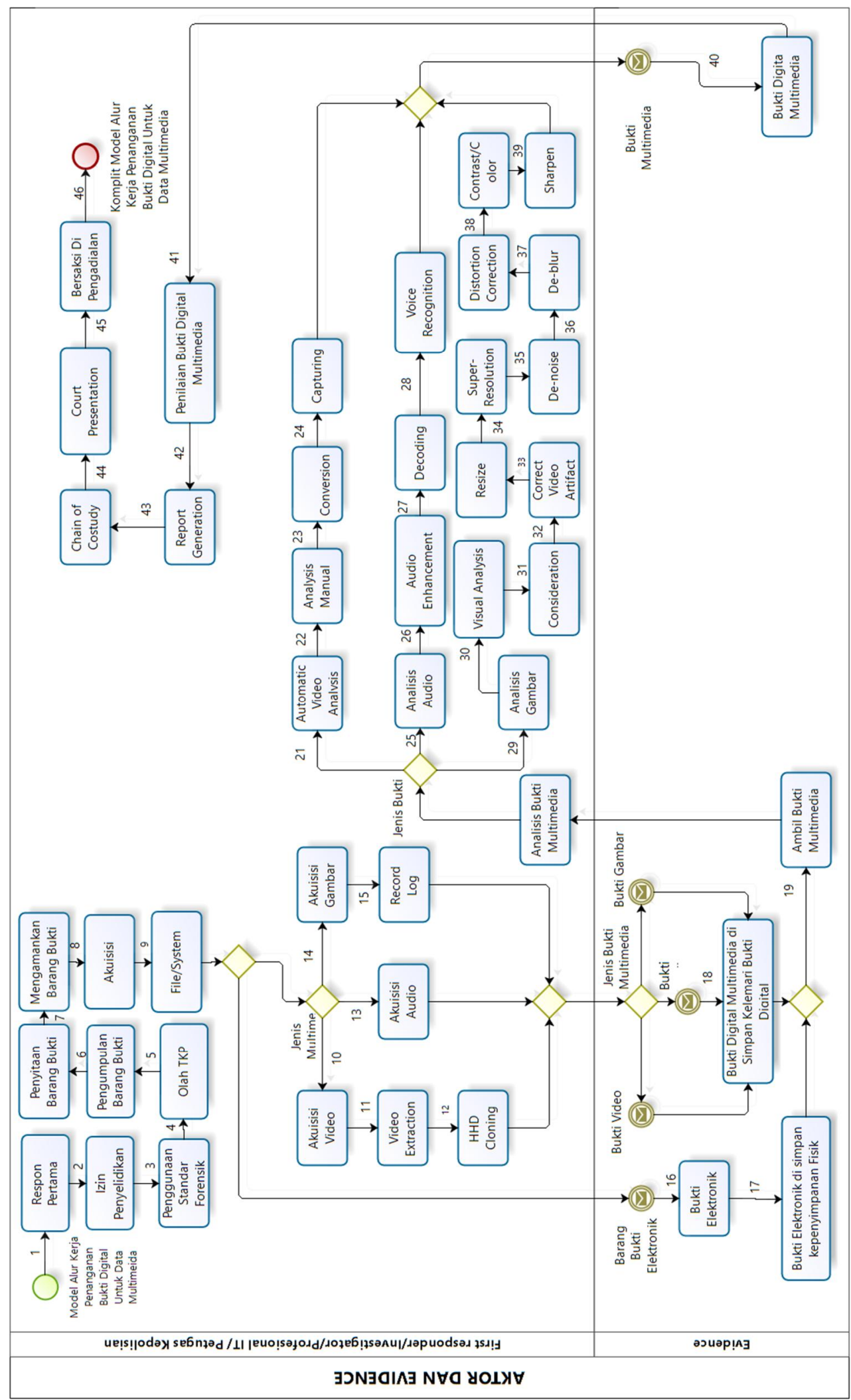

Gambar 4. Model Alur Kerja Penanganan Bukti Digital Untuk Data Multimedia 
Evaluasi dari model alur kerja penanganan bukti digital untuk data multimedia ini adalah belum bisa dipastikan relevan atau tidak dengan perkembangan keterlibatan aktor, bertambahnya jenis proses dan bukti multimedia di masa mendatang. Kebutuhan dalam penanganan bukti digital multimedia di lapangan sangat dinamis sehingga model alur kerja ini belum memiliki kontrol yang kuat untuk menjadi rujukan alur kerja yang berkelanjutan.

\subsection{Test}

Pada bagian pengujian ini menggunakan metode validasi bawaan tools Bizagi Modeler. Validasi ini merupakan proses untuk mengetahui seberapa tepat menggunakan elemen BPMN dalam membangun model alur kerja. Pengujian memastikan semua elemen terhubung dengan baik dengan memberikan nilai skenario 50 kali uji pengulangan untuk Aktor dan Evidence.

\section{KESIMPULAN}

Penelitian ini menghasilkan rancangan model alur kerja penanganan barang bukti digital untuk data multimedia yang diperoleh melalui proses metode design thinking dengan menggunakanan pendekatan Business Process and Notation (BPMN). Model alur ini mengklarifikasi bukti digital, penanganan bukti digital multimedia dan aktor yang terlibat. Model alur kerja ini hanya mengkolaborasikan aktor, evidence dan menggambarkan hubungan alur proses penanganan bukti digital multimedia.

\section{SARAN}

Output rancangan model alur kerja penanganan bukti digital untuk data multimedia hanya memetakan alur, aktor dan evidence. Sehingga penelitian selanjutnya dapat dikembangkan sehingga bisa menghasilkan model alur kerja untuk menangani berbagai kasus digital multimedia.

\section{DAFTAR PUSTAKA}

[1] Baryamureeba, V., \& Tushabe, F. 2004, The Enhanced Digital Investigation Process Model, Proceedings of The Digital Forensic Research Conference, DFRWS 2004 USA, $1-9$.

[2] Wongso, K., Media, D. I., Www, O., Com, K., Wr, U., Dgyhuwlvlqj, L., Iurp, U., Qhzv, W. K. H., Wklv, R. I., Friihh, F. D., \& Dqg, V. F. (n.d.). Media www.kompas.com ` By: $4(2)$.

[3] Patroli Siber. 2020, Https://Patrolisiber.Id/Statistic. https://patrolisiber.id/statistic

[4] Sunde, N., \& Marie, I. 2017, Non-technical Sources of Errors When Handling Digital Evidence within A Criminal Investigation, Department of Information Security and Communication Technology, Master (June 2017), 152. 
[5] Sari, P. L. 2018, Bentuk Kebijakan Amerika Serikat Terhadap Ancaman Cyber Crime China Sebagai Bentuk Upaya Proteksianisme Terhadap Keamanan Nasional, https://doi.org/10.25299/jkp.2018.vol.4(1).5307

[6] Kohn, M., \& Eloff, J. H. P. 2015, Framework for A Digital Forensic Investigation, January 2006.

[7] Caldelli, R., Amerini, I., Picchioni, F., \& Innocenti, M. 2010, Fast Image Clustering of Unknown Source Images, 2010 IEEE International Workshop on Information Forensics and Security, WIFS 2010, 1, 1-5. https://doi.org/10.1109/WIFS.2010.5711454

[8] Braid, M. 2001, Australian Computer Emergency Response Team Collecting Electronic Evidence After a System Compromise Why Collect Electronic Evidence? 1-13.

[9] Bradlley, S. 2007, Digital Evidence: Representation and Assurance, Thesis, 1-198.

[10] Cohen, F. 2009, Two Models of Digital Forensic Examination. 4th International Workshop on Systematic Approaches to Digital Forensic Engineering, SADFE 2009, 1(3), 42-53. https://doi.org/10.1109/SADFE.2009.8

[11] Rogers, M., Goldman, J., Mislan, R., Wedge, T., \& Debrota, S. 2006, Computer Forensics Field Triage Process Model, The Journal of Digital Forensics, Security and Law, 1(2), 19-38. https://doi.org/10.15394/jdfsl.2006.1004

[12] Korolev, S. V., \& Kuchanov, S. I. 1982, A Road Map for Digital Forensic Research, Polymer Science U.S.S.R., 24(3), 709-719. https://doi.org/10.1016/00323950(82)90064-8

[13] Perumal, S., \& Norwawi, N. 2010, Integrated Computer Forensic Investigation Model Based on Malaysian Standards, International Journal of Electronic Security and Digital Forensics, 3(2), 108-119. https://doi.org/10.1504/IJESDF.2010.033780

[14] Kent, K., \& Souppaya, M. 2006, Guide to Computer Security Log Management, Nist Special Publication.

[15] Lizarti, N., Sugiantoro, B., \& Prayudi, Y. 2017, Penerapan Composite Logic Dalam Mengkolaborasikan Framework Terkait Multimedia Forensik, JISKa, 2(1), 26-33.

[16] Ledesma, S. A. 2015, A Proposed Framework For Forensic Image Enhancement.

[17] Nuh Al-Azhar, M. 2012, Digital Forensics, 302.

[18] SWGDE. 2010, SWGDE-Minimum Requirements for Quality Assurance in The Processing of Digital and Multimedia Evidence, 1, 1-15.

[19] AlShaikh, A., \& Sedky, M. 2016, Post Incident Analysis Framework for Automated Video Forensic Investigation, International Journal of Computer Applications, 135(12), 1-7. https://doi.org/10.5120/ijca2016908300 
[20] Cosic. 2012, Chain of Custody and Life Cycle of Digital Evidence, Computer Technology and Application, 3(2012), 126-129.

[21] Subektiningsih. 2017, Pendekatan BPMN Untuk Pengembangan Digital Forensic Workflow Model Menggunakan Design Science Research Methodology, 169.

[22] Dam, R. F., \& Siang, T. Y. 2020, How to Select The Best Idea by The end of an Ideation Session, Retrieved from. 